Aristotle's Classification of Animals 



\section{PIERRE PELLEGRIN}

\section{ARISTOTLE'S \\ CLASSIFICATION \\ OF ANIMALS \\ BIOLOGY AND \\ THE CONCEPTUAL \\ UNITY OF THE \\ ARISTOTELIAN \\ CORPUS}

TRANSLATED BY

ANTHONY PREUS

UNIVERSITY OF CALIFORNIA PRESS BERKELEY · LOS ANGELES • LONDON 
Originally published as $L$ Classification des animaux chez Aristoce: Statut de la biologie et unité de l'aristorélisme,

(C) 1982 Société d'édition "Les Belles Lettres."

Revised edition.

University of California Press

Berkeley and Los Angeles, California

University of California Press, Ltd.

London, England

(C) 1986 by

The Regents of the University of Californiz

\section{Library of Congress Cataloging-in-Publication Data}

Pellegrin, Pierre.

Aristotle's classification of animals.

Translation of: La classification des animaux chez Aristote.

Rev. ed. produced through collaboration between

P. Pellegrin and A. Preus.

Bibliography: $p$.

Includes indexes.

1. Zoology - Classification. 2. Zoology -

Classification-History. 3. Aristotle. I. Preus,

Anthony. II. Title.

QL351.P4413 $1986 \quad 591^{\prime} .012 \quad 85-23305$

ISBN 0-520-05502-0 (2lk. paper)

Printed in the United States of America

123456789 
A toutes les bêtes... . 
